The Research Journal of the Costume Culture

[Original Article]

Received June 05, 2017

Revised July 27, 2017

Accepted August 11, 2017

${ }^{\dagger}$ Corresponding author

(chiclee89@naver.com)

ORCID

In sook Ahn

http://orcid.org/0000-0001-6960-4142

Sang Yun Lee

http://orcid.org/0000-0003-3397-0153

This work was supported by the Ministry of Education of the Republic of Korea and the National Research Foundation of Korea

(NRF-2016S1A5A8020516).

\section{Survey on the wearing of coveralls for automobile maintenance workers}

\author{
In Sook Ahn and Sang Yun Lee
}

Dept. of Fashion Design, Chung-Ang University, Korea

Dept. of Fashion, The Graduate School of Chung-Ang University, Korea*

\begin{abstract}
This research focuses on the condition of the coveralls that automobile maintenance workers wear. The objective of this survey is to conduct a thorough analysis on the quality of the coveralls and put forth suggestions for improving their quality. The research data were collected through interviews and the results are as follows. The participants in this research engage in a variety of types of maintenance work including oil changes and overall system checks and they usually wear extra-large-sized coveralls. The coveralls are generally worn during the winter for warmth and the company handles all purchasing and maintenance of the work clothes. Participants mentioned that certain parts of the clothes where they bend and stretch are cumbersome and areas around the knees and arms become easily tainted. They have also reported that although the coveralls are necessary, they are for the most part dissatisfied when it comes to the materials, design, and color. The participants have suggested that new coveralls would help to increase their work efficiency. As a result, it is concluded that the coveralls require much more development to meet the workers' needs and improvements need to be made on the functionality, aesthetics, and symbolic aspects of the design.
\end{abstract}

Keywords: auto mechanic(자동차 정비소), automobile mechanics(자동차 정비), coverall(상하일체작업복), work uniform(작업복)

\section{Introduction}

고도의 경제 성장과 기술의 발달로 자동차가 현대 생활의 필수 교통수단으로 자리 잡게 되면서, 자동차가 현대인의 삶에서 차지하는 비중이 높아지고 있다. 우리나라 의 자동차 등록대수는 해마다 점차 증가하여 2016년 기준 2,180 만 4천대를 달성하 였다. 국토교통부는 앞으로 2020년 자동차 등록대수가 2,500만대에 도달할 것으 
로 예측하며, 자동차관련 민원행정서비스의 품질제고 및 자동차 안전성 향상을 위한 자동차정책기본계획 을 수립하여 적극 추진할 계획이라고 밝혔다(Molit Statistics System, 2016b). 자동차의 수요와 공급이 늘 어감에 따라 자동차와 관련된 제반 산업들 또한 중요 성 및 역할이 확대되고 있으며, 그 중에서도 자동차 의 수명과 안전을 책임지는 자동차 정비업의 필요성 이 부각되고 있다. 국토교통부의 자동차관리사업종사 자 기초조사 자료에 따르면 2016년 9월 기준으로 정 비업 종사자 95,738 명, 매매업 종사자 35,482 명, 폐차 업 종사자 2,996 명, 성능 점검업 종사자 905 명 등으 로 정비업에 종사하는 정비사 수가 제일 높은 것으로 집계되었다(Molit Statistics System, 2016a).

자동차 정비사들은 단순한 정비 작업뿐만 아니라, 용접, 도장, 연마, 판금 등의 작업을 통한 열, 유해용 액, 분진 등 직접적인 산업재해요인에 노출되기 때문 에 이를 보호해줄 수 있도록 열적 단열성능이나 내화 학성, 내구성 등 기능성이 갖춰지고, 작업 효율 향상 을 위한 작업복이 요구된다. $\mathrm{Kim}(2007)$ 은 작업복 착 용의 목적이 단순히 작업 증진 및 신체 보호 등의 기 능성뿐만 아니라, 작업자의 정신적 기분상승이나, 작 업자의 개성, 직업에 대한 자부심 등을 갖기 위한 욕 구 등이 중요시 되고 있다고 하였다. 작업복을 착용 하는 작업자들의 니즈가 이제는 단순히 기능성만 갖 춰진 작업복을 넘어서 심미성, 표현성 등이 고려된 작업복을 원하는 것을 알 수 있다. 작업자의 신체를 보호하고 작업 효율을 높여주며, 개성 표출, 소속감 등이 갖춰진 작업복을 개발하기 위해서는 자동차 정 비업 종사자들의 작업복 착용 실태조사가 선행되어 착용하는 작업복의 종류와 실질적인 문제점 및 개선 점 등을 확인해야 할 필요가 있다고 사료된다.

국내 자동차 정비업체 작업복에 대한 연구를 살펴 보면, 자동차 정비 작업복의 기능적 디자인 연구(Kim, 2007), 자동차 정비업체 작업복 개발을 위한 연구 (Joung, 2008), 자동차 정비업체 근로자의 작업복 착 용만족도와 개선요구도(Kim \& Kweon, 2009), 자동 차 정비복의 패턴설계를 위한 맞음새와 동작적합성 평가(Kim \& Kweon, 2015), 자동차 정비 작업복의 패턴개발과 착의평가(Kim, 2016) 등 디자인, 패턴개 발, 착의평가의 연구들이 진행되었다. 하지만 선행 연구에서 실시한 자동차 정비업체 종사자들의 작업
복 착용실태조사는 Kim and Kweon(2009)의 연구에 서 조사된 것 외에 이후로 8년 이상 자동차 정비업 작업복에 관련한 착용 실태조사 연구가 전무한 실정 이다. 따라서 착용 실태조사를 실시하여 종사자들의 신체적, 심리적 변화가 적용된 새로운 데이터를 추출 하여 현 실정의 종사자들에게 맞는 작업복 개발을 위 한 기초 자료를 제공하는 것이 바람직할 것으로 사료 된다. 또한 본 연구에서는 선행연구 및 사전 면담조 사를 통해 자동차 정비업체 종사자들이 상하분리형 보다 상하일체형을 많이 착용하지만, 불편도가 높게 나타난 것을 파악하였으며, 이를 개선하기 위한 일체 형 작업복의 착용실태 및 문제점과 개선점을 조사하 고자 한다.

따라서 본 연구의 목적은 자동차 정비업체 종사자 들의 작업능률 향상 및 작업환경 개선을 위한 일체형 작업복 개발의 기초 단계 연구로서, 자동차 정비업체 종사자들을 대상으로 일체형 작업복 착용 실태조사 를 통해 향후 개발될 일체형 작업복 관련 연구들의 새로운 기준점을 제시함에 있다.

\section{Theoretical Background}

\section{Types and main activities of automobile me-} chanics

국내 자동차 정비업(한국 표준산업분류코드 95211) 은 자동차관리법 시행령에 따라서 자동차 종합정비업, 소형자동차 종합정비업, 자동차 전문정비업, 원동기 전문정비업 등으로 구분되어 규정하고 있다(Enforcement Decree of the Automobile Management Act, 2017). 종합정비업과 소형 종합정비업은 대상으로 하는 차 종만 다를 뿐, 같은 종합정비를 실시한다. 전문정비업 은 일반 자동차 소유자를 대상으로 점검이나 소모성 부품 및 소모품 교환 등을 실시하며, 원동기 전문정 비업은 자동차 원동기의 재생정비 등을 실시하는 업 무를 담당한다(Kim, 2011).

자동차 정비업의 전반적인 업무와 업무 중에 발생 되는 재해요인을 알아보기 위해 10 년 이상 경력의 정 비사 6명과 사전 면담 조사를 통해 자동차 정비업의 주요 작업과 발생되는 재해를 다음과 같이 분류했다. 첫째, 부품수리 및 교체는 일반적으로 차체 점검 후 이상 부품의 수리나 교체를 실시하는 작업으로 작업 
간에 자연스럽지 못한 자세나 무리한 동작으로 인한 근골격계 질환이 우려되는 작업이다. 둘째, 용접 작업 은 금속재료를 열을 이용하여 녹여서 가공 · 결합시 키는 작업으로 고열로 인한 화상이나 도장된 페인트 등이 열에 의해 발생하는 유해가스 등의 문제나 용접 작업 중 불씨 등으로 인한 화재가 발생할 수 있는 작 업이다. 셋째, 판금은 차체의 찌그러지거나 변형된 부 분을 원래의 모양으로 되돌리는 작업으로, 공구를 사 용하여 작업 중 신체적 무리나 상해를 입을 수 있는 작업이다. 넷째, 연마는 차체의 표면을 문질러 매끄럽 게 하는 작업으로 연마기에 신체 일부가 접촉되어 상 해가 발생하거나, 연마 후 분진에 의한 호흡기 질환이 발생할 수 있는 작업이다. 다섯째, 도장은 차체의 흠 집이나 판금 처리를 마친 부분들에 도색을 하는 작업 으로 페인트 분진이나 유기용제가 신체에 노출될 위 험이 있는 작업이다.

이처럼 자동차 정비업체 종사자들은 자동차와 관련 된 전반적인 업무를 수행하기 때문에 종사자들의 작업 환경 및 작업 업무에 따른 다양한 재해요인을 고려한 인체공학적 측면의 작업복 개발이 필요한 실정이다.

\section{Concept and scope of work clothes}

작업복은 작업 시 착용하는 의복으로 특수 의복의 범주에 속한다(Park \& Bae, 2008). 작업복은 산업 분 야에 따라서 종류가 다양하고, 작업환경에 따라 위험 요소 및 요구되는 보호기능이 다르기 때문에, 먼저 작 업환경을 파악하여 적합한 작업복을 선택해야 한다. 대표적인 보호용 작업복으로는 화학생물 방호복, 원 자력 발전소 작업복, 전기 기술자복, 소방복, 용접작업 복, 냉동창고 작업복, 무진복, 건설현장의 작업복, 방 염복, 방수복 등이 있다(Choi, Son, Do, Kim, \& Kang, 2003). 본 연구에서의 자동차 정비복 또한 정비 작업 간에 외부 작업 환경으로부터 신체를 보호하기 위한 용도로써 보호용 작업복으로 분류할 수 있다.

\section{Types and characteristics of automobile me-} chanic's work clothes

자동차 정비업체 종사자들이 착용하는 정비 작업복 의 형태는 크게 상하일체형(coverall)과 상하분리형으 로 나눌 수 있다. 상하일체형 작업복은 상하의가 연 결되어 있는 형태로 분리형 작업복에 비해 착 - 탈의
가 불편하다는 단점이 있지만, 보온성이 좋고, 작업 시 동작에 의해 상의나 하의가 벗겨질 문제가 없어 상해 의 우려가 적은 장점이 있다. 상하분리형 작업복은 상의는 점퍼스타일에 하의는 바지 형태의 작업복으 로 일체형 작업복에 비해서 착-탈의가 자유로운 장 점이 있지만, 작업 시 옷이 기계나 차체 등에 끼인다 거나 벗겨져, 일체형 작업복에 비해 상대적으로 신체 상해가 발생할 우려가 있다(Kim, 2016).

\section{Characteristics required for automobile me-} chanic's work uniform

작업복은 착용자의 생산능률 및 신체보호에 직접 적인 영향을 주기 때문에 기능성이 중요시 된다. 특 히 움직임이 많고 다양한 작업장에서의 작업복은 작 업장의 환경요소에 적합하며, 생리적 기능성과 동작 기능성이 충족될 수 있는 의복설계가 필요하다(Kim $\& \mathrm{Kim}, 2006)$. 기본적으로 작업복에 요구되는 특성 은 보건성, 장식성, 적응성, 내구성을 들 수 있으며 (Kim \& Suh, 2002), 활동유형에 따라 일상복과는 다 른 작업복을 착용함으로써 업무효율성과 편안함을 향상시킬 필요가 있다(Choi \& Ashdown, 2002). 수행 하는 업무에 따라 다양한 작업 재해 요인에 노출되는 자동차 정비업 특성상 기본적으로 안전성이 보장되 어야 하며. 작업 간에 불편함을 방지하고, 작업효율을 높여주기 위한 인체공학적 설계도 고려되어야 한다. 또한 작업 환경과 작업동작의 특성을 파악하여 이에 따라 요구되는 작업복의 기능성, 상징성, 심미성 등이 반영되어야 할 것이다.

\section{Research Methods}

본 연구는 자동차 정비업체 종사자들의 일체형 작 업복 착용 실태 및 문제점 등을 파악하기 위하여 서 울, 경기권 소재의 대기업 프랜차이즈 1 3급 정비업 체 종사자들을 대상으로 설문조사를 실시하였다. 연 구 목적에 부합하도록 자동차 정비업체 내에서도 실 질적으로 일체형 작업복을 착용하고 정비업을 실시 하는 정비사들을 대상으로 선정하여 일체형 작업복 을 착용하지 않는 사무직, 검사직 등을 수행하는 종 사자들은 대상에서 제외하였다. 두 차례에 걸친 사전 면담조사에 의하면 일반적으로 대기업 프랜차이즈 정 
비업체 종사자들의 작업복은 회사에서 일괄 구매하 여 착용하고 있었으며, 이러한 특성으로 인해 전국의 같은 대기업 프랜차이즈 정비업체 종사자들 간에 착 용되는 작업복의 큰 차이가 없을 것으로 사료된다.

본 조사에 앞서 사전 면담조사는 서울과 경기에 위 치한 대기업 프랜차이즈 정비업체 두 곳을 방문하여 2017년 3월 24일부터 3월 27일까지 3일에 걸쳐 관리 자 및 10 년 이상 경력의 정비사들 6 명을 대상으로 1 시 간 30 분에서 2 시간동안 FGI(Focus group interview) 방법을 실시하여 자료를 수집하였다. 설문 조사 기간 은 2017년 4월 17일부터 5월 1일까지 2주에 걸쳐 실 시되었으며, 자동차 정비업체 종사자들은 정해진 업 무시간 내에 최대한 많은 차량을 접수하여 다양한 업 무를 수행해야 하기 때문에, 따로 설문을 위한 개인 시간을 낼 수가 없어 설문을 진행하고 수거하는데 어 려움이 있었다. 총 300 부를 배포하여 189 부를 회수 (63.0\%)하였으며, 전 문항에 같은 답변을 하거나 미 응답이 많은 불성실 응답지 32 부를 제외한 157 부의 질문지를 최종적으로 본 연구 자료로 분석하였다. 설 문지는 수집된 사전 면담조사 내용과 Joung(2008)의 자동차 정비업체 작업복 개발을 위한 연구에서 사용 된 설문문항을 바탕으로 $\mathrm{Kim}$ and $\mathrm{Kim}(2006)$ 의 건설 현장 근로자의 작업복 실태조사 연구와, Kim and Kweon (2009)의 자동차 정비업체 근로자의 작업복 착용만족

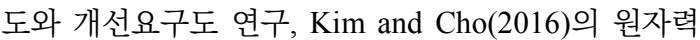
발전소 작업복의 착용만족도에 관한 연구를 참고로 작성하여 본 연구팀이 수정 및 보완하여 완성하였다. 설문 문항은 연령, 성별, 근무시간, 근무경력, 작업 유 형, 신장, 체중 등 조사대상자의 일반적 특성에 관한 질문(6문항)과 일체형 작업복의 필요성과 만족도, 착 용 계절, 착용 이유, 구입 방법, 착용 치수, 세탁 주기, 세탁 방법, 교체 주기, 오염 부위, 자주 움직이는 동작 부위, 동작적합성, 소재만족도, 세탁 관련 질문, 주관 식 문항 등 일체형 작업복에 관한 질문(15문항), 디자 인 만족도, 색상 만족도, 부자재 불편 경험, 휴대물품, 디자인 요구점, 주관식 문항 등 디자인에 관한 질문 (10문항), 소재구성과 관련된 기타 사항(4문항)으로 구성하였다(Table 1).

자료분석은 SPSS Statistics 23.0(IBM Software) 통 계프로그램을 사용하였으며, 기술통계, 빈도분석, 다 중응답분석, 교차분석을 통해 자동차 정비업 종사자
$<$ Table 1> Composition of questionnaire items

\begin{tabular}{l|c|c}
\hline $\begin{array}{c}\text { Classifi- } \\
\text { cation }\end{array}$ & $\begin{array}{c}\text { Number of } \\
\text { questions }\end{array}$ & References \\
\hline $\begin{array}{c}\text { General } \\
\text { characteristic } \\
\text { questions }\end{array}$ & 6 & Joung (2008) \\
\hline \multirow{2}{*}{$\begin{array}{c}\text { Work uniform } \\
\text { question }\end{array}$} & 15 & Kim \& Kim (2006) \\
\cline { 3 - 3 } \begin{tabular}{c} 
Design questions \\
\cline { 2 - 3 }
\end{tabular} & 10 & Kim \& Cho (2016) \\
\hline Fabric questions & 4 & Joung (2008) \\
\hline
\end{tabular}

들의 일체형 작업복 착용 실태와 만족도 및 개선요구 도를 분석하였다.

\section{Research Results}

\section{Demographic characteristics of the survey} subjects

\section{1) General characteristics}

조사 대상자 중 남성이 155 명(98.7\%), 여성이 2명 $(1.3 \%)$ 으로 남성이 대다수를 차지하였다. 조사대상자 의 연령은 20 대 종사자가 18 명(11.5\%), 30대 종사자가 45 명 $(28.7 \%), 40$ 대 종사자가 58 명(36.9\%), 50대 종사 자가 33 명 $(21.0 \%)$, 60 대 종사자가 3 명 $(1.9 \%)$ 이었다. 근 무경력은 10 년 이상이 73 명(46.5\%), 1년 이상 5년 미 만이 26명(16.6\%), 5년 이상 8년 미만이 21명(13.4\%), 8 년 이상 10 년 미만이 17 명(10.8\%), 6개월 이상 1년 미만이 10 명(6.4\%), 6 개월 미만이 10 명(6.4\%) 순으로 조사되었다. 1 일 근무 시간은 8 9시간이 80명(51.0\%) 으로 가장 높은 비율을 차지하였으며, 10 11시간이 72명(45.9\%), 12 13시간 이상이 5명(3.2\%)으로 나타 났다. 법정근로시간인 1 일 8 시간이 대체로 지켜지고 있었으나, 작업량에 따라 탄력적으로 연장하여 근무 하는 형태로 나타났다. 조사 대상자들의 주 수행 작업 으로는 오일교환 및 정비가 68 명(43.3\%)으로 대부분 을 차지하였으며, 용접, 판금, 연마, 도장, 오일교환 및 정비 등 전반적인 작업 일체를 한다는 응답이 60 명 (38.2\%)으로 그 다음을 차지했다. 


\section{2) Physical characteristics}

조사 대상자들의 신장은 $171 \sim 175 \mathrm{~cm}$ 이하가 60 명 $(38.2 \%)$ 로 가장 많았으며, $176 \sim 180 \mathrm{~cm}$ 이하가 40 명 (25.5\%), 166 170 $\mathrm{cm}$ 이하가 32명(20.4\%), $159 \sim 165 \mathrm{~cm}$ 이하가 16 명(10.2\%), $181 \sim 185 \mathrm{~cm}$ 이하가 7명(4.5\%), $186 \sim 190 \mathrm{~cm}$ 이하가 2명(1.3\%)순으로 나타났다. 체중은 $66 \sim 70 \mathrm{~kg}$ 이하가 38 명 $(24.2 \%), 56 \sim 60 \mathrm{~kg}$ 이하, $61 \sim 65 \mathrm{~kg}$ 이하, $71 \sim 55 \mathrm{~kg}$ 이하가 각각 23 명(14.6\%), 76 80kg 이 하가 20명(12.7\%), 81 85kg 이하가 13명, $50 \sim 55 \mathrm{~kg}$ 이 하가 6 명 $(3.8 \%), 86 \sim 90 \mathrm{~kg}$ 이하, 91 95kg 이하가 각각 5 명(3.2\%), $96 \mathrm{~kg}$ 이상이 1 명(0.6\%)순으로 나타났다.

\section{Status of wearing a coverall in automobile mechanics}

조사 대상자들의 일체형 작업복 착용 계절(복수응 답)을 조사한 결과 겨울이 94(56.3\%)로 가장 높았 으며 계절 무관하게 착용한다는 의견이 $59(35.3 \%)$, 봄 은 7(4.2\%), 가을은 $5(3.0 \%)$, 여름이 $2(1.2 \%)$ 순으로 나타났다. 일체형 작업복을 착용하는 이유(복수응답) 에는 보온성이 $80(42.0 \%)$ 으로 가장 높은 비율을 보였 으며, 보호성 $66(34.2 \%)$, 세탁물이 적음 $23(11.9 \%)$, 내의선택자유 $17(8.8 \%)$, 기타 6(3.1\%) 순으로 나타났 다(Table 2).

조사 대상자들의 작업복 착용 치수는 $\mathrm{XL}(100)$ 사

$<$ Table 2> Wearing season and reason for wearing (Multiple responses)

$(\%)$

\begin{tabular}{c|c|c}
\hline $\begin{array}{c}\text { Classifi- } \\
\text { cation }\end{array}$ & Answer & Frequency \\
\hline \multirow{4}{*}{$\begin{array}{c}\text { Wearing } \\
\text { season }\end{array}$} & Spring & $7(4.2)$ \\
\cline { 2 - 3 } & Summer & $2(1.2)$ \\
\cline { 2 - 3 } & Fall & $5(3.0)$ \\
\cline { 2 - 3 } & Winter & $94(56.3)$ \\
\hline \multirow{4}{*}{$\begin{array}{c}\text { Reason } \\
\text { for }\end{array}$} & All season & $59(35.3)$ \\
\cline { 2 - 3 } wearing & Heat reservance & $81(42.0)$ \\
\cline { 2 - 3 } & Prospective & $66(34.2)$ \\
\cline { 2 - 3 } & Lreedom of laundry & $23(11.9)$ \\
\hline
\end{tabular}

이즈를 착용이 64명(40.8\%)으로 가장 많은 비율을 차 지하였으며, $\mathrm{L}(95)$ 사이즈가 33명(21.0\%), XXL(105) 사이즈가 31명(19.7\%), $\mathrm{M}(90), \mathrm{XXL}(110)$ 사이즈가 13 명 $(8.3 \%), \mathrm{S}(85)$ 사이즈가 2명(13\%), XXXL(115)사 이즈가 1 명 $(0.6 \%)$ 로 나타났다. 종사자들의 신장과 체 중이 일체형 작업복 치수 선정에 영향이 있는지 알아 보기 위해 상관분석을 실시한 결과, 작업복의 착용 치수는 신장보다 체중에 더 유의한 상관을 보여 작업 복 치수 선택에 있어서 체중에 따라 영향이 있을 것 으로 사료된다.

\section{Purchase and manage of coverall}

조사 대상자들 중 일체형 작업복을 회사에서 일괄 적으로 구입한다는 응답은 131 명(83.4\%)으로 가장 높았으며, 본인이 직접 구입하는 응답은 26 명 $(16.6 \%)$ 이었다. 이를 통해 프랜차이즈 기업은 주로 본사에서 일괄적으로 작업복을 선정하여 각 업체로 공급하는 시스템을 사용하고 있음을 알 수 있다.

일체형 작업복의 교체주기를 묻는 질문에 1 년마다 한 번씩 교체한다는 응답이 59명(37.6\%)이었으며, 2년 에 한 번씩 교체 41 명(26.1\%), 6개월마다 한 번씩 교 체 35 명(22.3\%), 3개월마다 한 번씩 교체 13 명(8.3\%), 교체 안 해도 된다가 9명(5.7\%) 순으로 응답했다.

조사 대상자들의 일체형 작업복 세탁은 회사에서 단체로 일괄적으로 한다는 응답이 86명(54.8\%), 직접 세탁한다는 응답이 71명(45.2\%)으로 나타났다. 세탁주 기는 2 3일에 한 번씩 한다는 응답이 85 명(54.1\%)으 로 가장 높은 비율을 차지하였으며, 일주일에 한번 세탁이 59명(37.6\%), 매일 세탁이 9명(5.7\%), 세탁하 지 않는다는 응답은 4 명 $(2.5 \%)$ 으로 나타나, 자동차 정비업 특성상 작업 간에 기름이나 흙, 먼지, 땀 등에 의해 오염이 자주 발생되기 때문에 비교적 세탁을 자 주 하고 있음이 나타났다.

작업 시 오염이 심한 작업복 부위를 묻는 질문(복 수응답)에 하체에서는 무릎부위가 $128(11.6 \%)$ 로 가 장 오염이 잘 되는 것으로 응답하였고, 상체에서는 팔 부위가 $114(10.3 \%)$ 으로 가장 높게 나타났다. 그 다음으로 허벅지 105(9.5\%), 소매끝 104(9.4\%) 등이 오염된다고 응답하였으며, 자동차 정비업 작업 특성 상 팔을 사용하거나 무릎을 굽히는 동작이 많아 해당 부위에 오염이 자주 발생하기 때문에, 방오 기능이 갖 
<Table 3> Main action (Multiple responses)

$(\%)$

\begin{tabular}{c|c|c}
\hline Classification & Answer & Frequency \\
\hline \multirow{4}{*}{$\begin{array}{c}\text { Main action } \\
\text { (Multiple } \\
\text { responses) }\end{array}$} & Shoulder and arm & $91(31.1)$ \\
\cline { 2 - 3 } & Bending of waist & $86(29.4)$ \\
\cline { 2 - 3 } & Spread legs & 85(29.0) \\
\cline { 2 - 3 } & Neck & $10(3.4)$ \\
\hline
\end{tabular}

춰진 소재의 사용이 필요할 것으로 사료된다.

\section{Moving fitness of coverall}

\section{1) Main action}

일체형 작업복을 착용하고 주로 하는 동작을 묻는 질문(복수응답)에 어깨 및 팔 동작이 91명(31.1\%)로 가장 많다고 응답하였으며, 그 다음으로는 허리 구부 림 동작 86명(29.4\%), 무릎 구부림 동작 85명(29.0\%), 다리 벌림 동작 21 명 $(7.2 \%)$, 목 동작 10 명(3.4\%) 순 으로 응답하였다(Table 3).

\section{2) Moving fitness}

일체형 작업복을 동작에 따라 부위별 불편도를 1점, ‘매우 당긴다'부터 5점 '매우 편하다'로 5점 리커트 척도로 평가하여 조사해 본 결과, 가장 불편한 부위로 는 허리를 펴고 다리를 반쯤 구부리고 두 팔을 들고 작업할 때 겨드랑이가 가장 불편한 것으로 나타났다.

동작 항목별 부위 불편도를 살펴보면 허리를 펴고 다리를 반쯤 구부리고 두 팔을 들고 작업할 때 겨드 랑이 부위가 당긴다는 응답이 53명(33.8\%), 매우 당 긴다는 응답이 23 명 $(14.6 \%)$ 으로 나타났으며, 바지가 랑이 부위는 당긴다는 응답이 45 명 $(28.7 \%)$, 매우 당 긴다는 응답이 20 명(12.7\%)으로 나타났고, 무릎 부위 는 당긴다는 응답이 46 명 $(29.3 \%)$, 매우 당긴다는 응 답이 12 명(7.6\%)으로 나타났다.

상체를 앞으로 굽히는 동작 시 팔 부위가 당긴다는 응답이 41명(26.1\%), 매우 당긴다는 응답이 9명(5.7\%) 으로 나타났다. 등 부위는 당긴다는 응답이 55 명 (35.0\%), 매우 당긴다는 응답이 20명(12.7\%)으로 나 타났으며, 어깨부위는 당긴다는 응답이 57명(36.3\%), 매우 당긴다는 응답이 12 명(7.6\%)으로 나타났다.
한쪽 다리를 뻗고 다른 한쪽 다리는 구부리고 작업 하는 동작 시 엉덩이 부위가 당긴다는 응답이 43 명 (27.4\%), 매우 당긴다는 응답이 17명(10.8\%)으로 나타 났다. 또 무릎 부위는 당긴다는 응답이 45 명 $(28.7 \%)$, 매우 당긴다는 응답이 17 명(10.8\%)으로 나타났으며, 허리부위는 당긴다는 응답이 46 명(29.3\%), 매우 당긴 다는 응답이 13 명 $(8.3 \%)$ 으로 나타났다.

한쪽 다리를 구부리고 두 팔로 작업하는 동작 시, 팔 부위가 당긴다는 응답은 42 명 $(26.8 \%)$, 매우 당긴다 는 응답이 13 명 $(8.3 \%)$ 으로 나타났다. 등 부위는 당긴 다는 응답이 39 명 $(24.8 \%)$, 매우 당긴다는 응답이 13 명 $(8.3 \%)$ 으로 나타났다. 어깨 부위는 당긴다는 응답이 47명(29.9\%), 매우 당긴다는 응답이 17 명(10.8\%)으로 나타났다.

누워서 위를 보면서 작업하는 동작 시, 등 부위가 당 긴다는 응답은 32 명(20.4\%), 매우 당긴다는 응답은 10 명 $(6.4 \%)$ 으로 나타났다. 팔 부위가 당긴다는 응답은 47 명(29.9\%), 매우 당긴다는 응답은 13 명 $(8.3 \%)$ 으로 나 타났으며, 어깨 부위가 당긴다는 응답은 51명(32.5\%), 매우 당긴다는 응답은 13 명 $(8.3 \%)$ 으로 나타났다.

쪼그려 앉는 동작 시 허리 부위가 당긴다는 응답은 55 명(35.0\%), 매우 당긴다는 응답은 21명(13.4\%)였으 며, 뒷목 부위가 당긴다는 응답은 42 명 $(26.8 \%)$, 매우 당긴다는 응답은 15 명 $(9.6 \%)$ 으로 나타났다. 무릎 부위 가 당긴다는 응답은 59명(37.6\%), 매우 당긴다는 응답 은 17 명 $(10.8 \%)$ 으로 나타났다. 대체로 굽혀지거나 신 장되는 동작 시 그 부위에 불편함을 느끼는 것을 알 수 있었으며, 일체형 작업복 개발 시 동작 적합성을 높이기 위한 패턴 수정 및 소재 사용이 필요할 것으 로 사료된다.

\section{Necessity and satisfaction of coverall}

\section{1) Necessity and satisfaction}

일체형 작업복의 필요성 및 만족도를 평가하기 위 해 '작업복의 필요성', '현 작업복의 만족도', '작업복 개선에 따른 능률향상 기대' 등 총 3 문항을 1점 '매우 그렇지 않다'부터 5점 '매우 그렇다’로 5점 리커트 척 도를 조사한 결과, 작업 시 일체형 작업복의 필요성 은 평균 3점보다 이상인 평균 3.20 으로 나타나, 자동 차 정비업 작업 시 일체형 작업복이 필요한 것으로 나타났으며, 현 작업복에 대한 만족도는 평균 2.64로 
$<$ Table $4>$ Necessity and satisfaction of coverall

$(\%)$

\begin{tabular}{c|c|c|c|c|c|c}
\hline Classification & 1 & 2 & 3 & 4 & 5 & Mean(SD) \\
\hline Necessity of coverall & $11(7.0)$ & $25(15.9)$ & $54(34.4)$ & $56(35.7)$ & $11(7.0)$ & $3.20(1.022)$ \\
\hline Satisfaction of coverall & $26(16.6)$ & $37(23.6)$ & $67(42.7)$ & $21(13.4)$ & $6(3.8)$ & $2.64(1.032)$ \\
\hline $\begin{array}{c}\text { Expect to improve efficiency } \\
\text { by improving work clothes }\end{array}$ & $3(1.9)$ & $15(9.6)$ & $58(36.9)$ & $72(45.9)$ & $9(5.7)$ & $3.44(0.819)$ \\
\hline
\end{tabular}

불만족하는 것으로 나타났다. 또한 일체형 작업복이 개선되었을 때 작업 능률이 향상될 것이라는 기대도 는 평균 3.44 로 높게 나타나, 현 작업복의 개선을 통 해 작업 능률을 향상시킬 필요가 있을 것으로 사료된 다(Table 4).

\section{2) Satisfaction of fabric}

현재 착용하는 일체형 작업복의 소재 만족도를 알 아보기 위해 ‘통기성', ‘흡습성', ‘내마모성', ‘신축성', ‘방오성', ‘속건성' 등 총 6문항을 5점 리커트 척도를 통해 1점은 '매우 불만족한다'로 5점은 '매우 그렇다' 로 점수를 평가하였다(Table 5). 전 항목의 점수가 평 균 3점에 미치지 못하여 조사 대상자들의 소재 만족
도는 불만족한 것을 알 수 있다. 특히 '통기성' 항목 의 점수가 가장 낮은 만족도 점수를 보이고 있어, 통 기성이 우수한 소재 사용을 통해 기능성 개선이 필요 할 것으로 사료된다.

\section{3) Satisfaction of design}

일체형 작업복의 디자인 만족도를 평가하기 위해 ‘전체적인 디자인(형태)', ‘착용 후 모양(핏)', ‘활동에 무리 없는 디자인', ‘소속감/자부심을 주는 디자인', ‘주머니, 지퍼 등 부속디자인' 등 총 5 문항을 질문하 였다. '매우 불만족한다'를 1점으로 하고 '매우 만족 한다'를 5점으로 하여 5점 리커트 척도를 통해 점수 를 평가하였다(Table 6). 전 문항의 평균이 3점보다 낮

$<$ Table 5> Satisfaction of fabric

$(\%)$

\begin{tabular}{c|c|c|c|c|c|c}
\hline Classification & 1 & 2 & 3 & 4 & 5 & Mean(SD) \\
\hline Breathable & $38(24.2)$ & $65(41.4)$ & $50(31.8)$ & $4(2.5)$ & $0(0.0)$ & $2.13(0.806)$ \\
\hline Hygroscopicity & $26(16.6)$ & $70(44.6)$ & $55(35.0)$ & $4(2.5)$ & $2(1.3)$ & $2.27(0.813)$ \\
\hline Wear resistance & $7(4.5)$ & $44(28.0)$ & $100(63.7)$ & $6(3.8)$ & $0(0.0)$ & $2.67(0.624)$ \\
\hline Elasticity & $16(10.2)$ & $73(46.5)$ & $56(35.7)$ & $12(7.6)$ & $0(0.0)$ & $2.41(0.776)$ \\
\hline Antistaining & $17(10.8)$ & $64(40.8)$ & $67(42.7)$ & $9(5.7)$ & $0(0.0)$ & $2.43(0.762)$ \\
\hline Quick drying & $14(8.9)$ & $73(46.5)$ & $67(42.7)$ & $3(1.9)$ & $0(0.0)$ & $2.38(0.674)$ \\
\hline
\end{tabular}

$<$ Table 6> Satisfaction of design

$(\%)$

\begin{tabular}{c|c|c|c|c|c|c}
\hline Classification & 1 & 2 & 3 & 4 & 5 & Mean(SD) \\
\hline Silhouette & $11(7.0)$ & $27(17.2)$ & $100(63.7)$ & $17(10.8)$ & $2(1.3)$ & $2.82(0.764)$ \\
\hline Fit & $13(8.3)$ & $38(24.2)$ & $89(56.7)$ & $14(8.9)$ & $3(1.9)$ & $2.72(0.815)$ \\
\hline Activity & $12(7.6)$ & $26(16.6)$ & $97(61.8)$ & $20(12.7)$ & $2(1.3)$ & $2.83(0.791)$ \\
\hline Sense of belong/Self-esteem & $14(8.9)$ & $36(22.9)$ & $88(56.1)$ & $17(10.8)$ & $2(1.3)$ & $2.73(0.821)$ \\
\hline Accessory design & $8(5.1)$ & $38(24.2)$ & $92(58.6)$ & $17(10.8)$ & $2(1.3)$ & $2.79(0.751)$ \\
\hline
\end{tabular}


$<$ Table 7> Satisfaction of color

\begin{tabular}{c|c|c|c|c|c|c}
\hline Classification & 1 & 2 & 3 & 4 & 5 & Mean $(S D)$ \\
\hline Overall color & $11(7.0)$ & $27(17.2)$ & $100(63.7)$ & $14(8.9)$ & $5(3.2)$ & $2.84(0.805)$ \\
\hline Colors without eye stress & $7(4.5)$ & $12(7.6)$ & $108(68.8)$ & $26(16.6)$ & $4(2.5)$ & $3.05(0.723)$ \\
\hline Colors not to sight of pollution & $8(5.1)$ & $35(22.3)$ & $82(52.2)$ & $27(17.2)$ & $5(3.2)$ & $2.91(0.850)$ \\
\hline Colors to improve work efficiency & $14(8.9)$ & $27(17.2)$ & $87(55.4)$ & $24(15.3)$ & $5(3.2)$ & $2.87(0.892)$ \\
\hline
\end{tabular}

게 평가된 것으로 보아, 현재 착용하는 일체형 작업 복의 디자인이 불만족스러운 것으로 나타났다. 특히 착용 후 ‘모양(핏)'과 ‘소속감/자부심을 주는 디자인' 항목에 만족도가 낮아 인체공학적 측면에서의 패턴 개 발뿐만 아니라 착용자의 긍정적 이미지 및 직무만족 도 향상을 위한 상징성 측면에서의 디자인 개발이 고 려되어야 할 것으로 사료된다.

\section{4) Satisfaction of color}

일체형 작업복의 색상 만족도를 평가하기 위해 '전 체적인 색상, ‘눈에 무리를 주지 않는 색상’, ‘오염이 안 띄는 색상’, ‘작업 능률 향상 색상’ 등 총 4문항을 질문하였다(Table 7). '매우 불만족한다'를 1점, '매우 만족한다'를 5점으로 하여 평가하도록 하였다. '눈에 무리를 주지 않는 색상' 항목을 제외한 전 문항의 평 균이 3점보다 낮아서 현재 착용하는 일체형 작업복의 색상은 정비업 종사자들에게 불만족스러운 것으로 나타났으며, 종사자들이 선호하는 색상으로 개선이 필요할 것으로 사료된다.

\section{Discomforts and required improvements of} coverall

일체형 작업복의 불편사항을 알아보기 위해 주관식 형 문항을 만들어 자유롭게 의견을 작성하도록 하였 다. 공통적으로 나타난 불편 사항으로는 '용변 볼 때 탈 의가 불편하다'는 점과 '일상복으로 환복할 때', '밑 위와 다리 밑단이 당겨져 불편하다', ‘통기성이 부족 하다', '신축성이 매우 부족하다', '땀흡수가 잘 안된 다', '세탁이 잘 안 된다' 등의 의견이었다.

일체형 작업복의 소재 및 디자인 개선 요구사항을 조사하기 위해 '부자재 불편 여부', ‘작업 시 휴대물 품', ‘앞주머니 개수', ‘볼펜꽂이 주머니 사용 여부', ‘핸드폰 주머니 필요 여부', '탈부착 후드 필요 여부',
'방오 소재 필요', '신축 소재 필요' 등 총 8 문항을 질 문하였다. 스냅 단추나 벨크로가 성능이 저하되어 불 편한 적이 있는지에 대한 문항에 127 명 $(80.9 \%)$ 이 불 편함을 경험한 적이 있다고 응답하여 개선이 필요한 것으로 나타났다. 작업 시 작업복에 휴대하는 물품 (복수응답)에 대한 응답으로 핸드폰이 135명(34.5\%)로 가장 많았으며 그 다음으로 장갑 79 명 $(20.2 \%)$, 담배 74명(18.9\%), 지갑 59명(15.1\%), 공구 44명(11.3\%) 순으로 나타났다.

일체형 작업복의 적당한 앞주머니의 개수를 묻는 문항에는 다수의 응답이 2 개(60.5\%)로, 일반적인 작 업복의 앞주머니 개수와 동일하게 나타났다. 주로 팔 옆 부분에 달려있는 볼펜꽂이 주머니 사용여부를 묻 는 문항에 사용한다는 응답이 113 명(72.0\%)으로, 핸드 폰 주머니가 따로 필요하다는 응답이 133 명 $(84.7 \%)$ 으로 높게 나타났다. 소매 부리와 바지 부리에 여밈 벨크로가 필요한 지에 대한 문항에 필요하다는 응답 이 122 명(77.7\%)로 나타나 작업 간에 분진이나 흙, 먼 지 등이 작업복 내부로 들어가지 않게 착용자가 조절 할 수 있도록 디자인해야 할 것으로 사료된다. 탈부착 할 수 있는 후드(모자)가 필요한지에 대한 문항에 필 요 없다는 응답이 103명(65.6\%)으로 높게 나타났으 며, 작업 간에 부착되어 있는 후드가 거추장스럽다고 느껴져 필요 없다고 한 것으로 사료된다. 기름때 등 의 오염물이 잘 묻지 않는 방오 가공된 소재의 사용을 원한다는 응답이 146 명(93.0\%), 신축성 있는 소재의 사용을 원한다는 응답은 151 명(96.2\%)으로 높게 나 타나 일체형 작업복 개발 시 방오 소재 및 신축 소재 의 사용이 필요할 것으로 사료된다.

\section{Discussion and Conclusion}

본 연구는 자동차 정비업체 종사자들의 작업능률 
향상 및 작업환경 개선을 위한 일체형 작업복 개발의 기초 단계 연구로서 자동차 정비업체 종사자들을 대 상으로 일체형 작업복 착용실태조사를 통해 향후 개 발될 일체형 작업복 관련 연구들의 새로운 기준점을 제시하며, 기존 선행연구와는 차별화된 일체형 작업 복의 문제점을 조사하고, 개선점을 도출하기 위해 서 울, 경기 대기업 프랜차이즈 1 3급 정비업체 종사자 들을 대상으로 설문조사를 실시하였다. 이상의 조사 된 결과를 토대로 다음과 같은 결론 및 시사점을 제 시할 수 있다.

첫째, 대부분의 선행연구에서 춘추용 일체형 작업 복에 관한 연구가 주를 이루고 있었으나, 실제 일체 형 작업복의 착용 현황을 조사해보니 동절기에 보온 성을 위해 착용한다는 다수의 의견이 나타났다. 실외 에서 작업을 하는 정비업 특성상 환경적 요인에 따른 영향을 고려해야 하기 때문에, 주로 겨울에 보온성이 우수한 일체형 작업복을 선택하는 것으로 보이며, 또 한 신체의 노출이 상대적으로 적은 일체형 작업복을 통해 작업 간에 상해의 우려를 줄이고자 일체형 작업 복을 착용하는 것으로 사료된다. 자동차 정비업체 종 사자들은 특정 작업 시에만 일체형 작업복을 착용할 것이라고 예상했지만, 전반적인 작업 일체(용접, 판 금, 도장, 오일 및 정비)를 수행하며, 일체형 작업복을 착용하는 것으로 확인되었다. 기존의 선행연구들이 작업복의 치수 맞음새, 동작적합성 등을 고려한 작업 복 개발에 그쳤으나, 각각의 수행 작업에 따른 재해 요인이 고려된 일체형 작업복 개발 연구가 필요할 것 으로 사료된다.

둘째, 작업복은 주로 회사에서 일괄적으로 구입하 여 제공하는 형태이며, 작업복 세탁의 경우, 대부분 회사에서 일괄적으로 이루어지고 있으나, 직접 세탁 하는 비율도 높게 나타나 소재에 따른 세탁방법 및 관리방법 등을 라벨에 명시하여 종사자들로 하여금 잘못된 세탁으로 인해 발생하는 작업복의 불편사항 을 미연에 방지해야 할 것이다. 또한 비교적 긴 주기 인 1 2년마다 작업복을 교체하는 것이 적당하다고 응답하는 것으로 보아, 작업간에 발생되는 오염으로 위생 및 미관상의 문제나 잦은 세탁으로 인한 성능 저하 등의 문제를 방지하는 경제적인 작업복 착용을 위한 개발이 이루어져야 할 것으로 사료된다

셋째, 작업 시 주로 발생하는 오염부위는 무릎과 팔,
허벅지, 소매 끝 등으로, 이는 선행연구(Bae, 2001; Joung, 2008)들과 맥을 같이 하며, 전체적으로 일체형 작업 복에 방오성 소재를 사용하여 작업복의 단가를 높이 기 보다는 오염이 자주 발생하는 특정 부위에 방오 기능이 더해진 소재를 부분적으로 사용하여 오염을 방지하는 것이 경제적일 것으로 사료된다. 일체형 작 업복을 착용하고, 주로 하는 동작은 어깨 및 팔 동작 으로 작업복 개발 시 상체 부위에 무나 플리츠, 다트 등 을 추가하여 활동에 무리가 없도록 디자인되어야 할 것이다. 또한 일체형 작업복을 착용하고 굽혀지거나 신장되는 동작 시 불편함을 느끼는 것으로 나타나, 패 턴 수정 및 신축성 있는 소재 사용이 필요할 것으로 사료된다.

넷째, 자동차 정비업체 종사자들은 대체로 현재 착 용하는 일체형 작업복에 대해서는 불만족하는 것으 로 나타났으며, 개선을 통해 작업 능률의 향상 기대 도가 높은 것으로 나타나, 종합적으로 자동차 정비업 체 종사자들의 일체형 작업복 착용 실태 조사를 통해 개선된 작업복 개발이 필요하다. 소재 개선에 대한 필요성이 선행연구 및 본 연구를 통해 계속 확인되고 있지만, 대부분 비용 절감을 위해 소재의 기능성이 떨 어지는 저가의 작업복을 구입하여 제공하고 있어, 가 격과 품질의 절충점을 찾아 경제적이고 합당한 가격 및 양질의 상품 개발이 이루어져야 할 것이다. 디자 인 측면에서는 착용 후 모양(핏)과 소속감/자부심을 주는 디자인 만족도가 낮게 나타났다. 대기업 프랜차 이즈 정비업체 정비사들의 작업복은 단순히 작업할 때 착용하는 의복의 의미뿐만 아니라, 기업의 이미지 가 반영된 작업복을 통해 고객들에게 기업의 이미지 를 전달하는데 큰 역할을 차지하며, 정비사의 외관상 이미지가 곧 고객에게 기업의 이미지로 이어지게 된 다. 사전면담 조사에서 한 정비사는 일체형 작업복을 입으면 다른 사람들에게 노동자 이미지로 비치는 것 이 싫고, 자존심이 상한다는 의견도 있었다. 또한 선 행연구(Choi, 2014; Song, 2008)에서 종사자들의 착 용하는 복장에 대한 만족도가 직무 만족도 및 직무 성과에 영향을 미친다는 결과가 확인되고 있어, 자동 차 정비사들의 직무만족도 향상을 위한 상징성 측면 에서의 디자인 개발이 고려될 필요가 있을 것으로 사 료된다.

이상으로 자동차 정비업체 종사자들의 일체형 작 
업복 착의 실태 및 문제점, 개선요구점 등을 종합해 보면 일체형 작업복은 필요성에 비해 현재 착용되는 일체형 작업복의 개선도가 미약하며, 전반적인 개선 을 통해 종사자들의 니즈를 충족할 수 있도록 기능 적, 심미적, 상징적 측면에서의 디자인 및 패턴 설계 를 실시해야 할 것으로 사료된다. 본 연구의 제한점 으로는 대기업 프랜차이즈 정비업체 종사자들을 대 상으로 설문을 진행하여 개인 소규모 경정비 업체 종 사자들의 착용실태를 파악하지 못해 한정적이었다는 점과 조사대상자들의 바쁜 업무로 인해 다양한 직무 를 수행하는 종사자들의 좀 더 심층적인 데이터 수집 이 어려웠다는 제한점이 있지만, 개인 소규모 경정비 업체는 대기업 프랜차이즈 정비업체와 같이 유니폼 형태의 작업복을 착용하지 않기 때문에, 일관된 데이 터를 얻을 수 없을 것으로 판단해 제외하였으며, 조 사대상자들의 착용 작업복에 대한 실질적인 데이터 를 얻기 위해 근무 간 쉬는 시간, 점심시간, 출퇴근시 간 등을 이용하여 종사자들의 의견을 수집하였다.

\section{References}

Bae, H. -S. (2001). Status quo analysis on the clothing practice of automaker's uniform. Family and Environment Research, 39(7), 115-124.

Choi, H. H. (2014). Effects of airlines workers' uniform satisfaction on job satisfaction: Comparison of casual wear with formal wear. Unpublished master's thesis, Korea Aerospace University, Goyang, Korea.

Choi, H. S., Son, B. H., Do, W. H., Kim, E. K., \& Kang, Y. S. (2003). Technical wear design. Seoul: Suhaksa.

Choi, M.-S., \& Ashdown, S. P. (2002). The design and testing of work clothing for female pear farmers. Clothing and Textiles Research Journal, 20(4), 253-263. doi:10.1177/0887302X0202000409

Enforcement Decree of the Automobile Management Act, No. 27960, Article 12 (2017).

Joung, K. A. (2008). A study on the development of auto-repair worker's work clothing. Unpublished master's thesis, Ewha Womans University, Seoul,
Korea.

Kim, H.-R. \& Suh, M.-A. (2002). A research of worker's uniform in the mechanical industry. The Research Journal of the Costume Culture, 10(6), 718-734.

Kim, J.-H. (2016). Development of patterns and wearing test for auto mechanic's coverall. Unpublished doctoral dissertation, Chungbuk National University, Chungcheongbuk-do, Korea.

Kim, J. H., \& Kweon, S. A. (2009). The wearing satisfaction and demand of improvement for working uniform in car service firms. Korean Journal of Human Ecology, 18(2), 407-418.

Kim, J. H., \& Kweon, S. A. (2015). Design of a pattern according to the fitness of automobile repair uniforms and their evaluation of appropriateness for movement. Journal of Human Ecology, 19(1), 79-87.

Kim, S. D. (2011). Study for direction of auto mechanic industry in Korea. Unpublished master's thesis, Korea University, Seoul, Korea.

Kim, S.-S., \& Kim, H.-E. (2006). A research study on construction field worker's working uniform. Fashion \& Textile Research Journal, 8(2), 203208.

Kim, Y. H. (2007). A functional design of auto mechanic's coverall. Journal of the Korean Society of Clothing and Textiles, 31(4), 531-539. doi:10. 5850/JKSCT.2007.31.4.531

Kim, Y. H., \& Cho, K. S. (2016). A study on the satisfaction of working uniform on nuclear power plant. Fashion \& Textile Research Journal, 18(5), 668-676. doi:10.5805/SFTI.2016.18.5.668

Molit Statistics System. (2016a), 자동차관리사업자업 체현황분기 [Status of automobile Management project (quarter)]. Retrieved April 20, 2017, from http://stat.molit.go.kr/portal/cate/viewChk.do?hRsI $\mathrm{d}=437 \& \mathrm{hFormId}=4392 \& \mathrm{hKeyWord}=$ 자동차관리 사업자업체현황분기\&hTotalFlag $=\mathrm{Y}$

Molit Statistics System. (2016b). 자동차 등록 현황 [Total registered moter vehicles]. Retrieved April 
20, 2017, from http://www.index.go.kr/potal/main/ EachDtlPageDetail.do?idx_cd=1257

Park, G.-A. \& Bae, H.-S. (2008). A study on the working clothes in the Changwon National Industrial Complex: Considering clothing performance and motion factors in work places. Journal of the
Korean Society of Clothing and Textiles, 32(10), 1571-1583. doi:10.5850/JKSCT.2008.32.10.1571

Song, H. J. (2008). The Influence of casino employees uniform in job Satisfaction and customer orientation. Unpublished master's thesis, Kyonggi University, Seoul, Korea. 